\title{
ИГРАТА КАКО АКТИВНОСТ И ИГРАТА КАКО ТЕРАПИЈА КАЈ ДЕЦАТА СО ПРЕЧКИ ВО РАЗВОЈОТ
}

\section{Кратка содржина}

Играта претставува нормална експресија кај децата, која може да биде под влијание на етничката припадност, јазикот, религијата или други културни аспекти. Не само што има централно место, туку е и круцијална за детскиот развој, интензивното моторно и сензорно стимулирање, кои настануваат како резултат на играта, помагаат во нормалниот развој на мозокот и спречуваат губење на невроните. Од друга страна, играта не е значајна само за промовирање на нормалниот детски развој, таа има и непроченлива терапевтска моќ.

Основната чел на студијата беше да се детерминираат фреквенцијата и видот на игровни активности кои ги преферираат деча со пречки во развојот, како и да се потенцира терапевтската моќ на играта. Беа применети методот на компаративна и дескриптивна анализа и методот на генерализачија. Од техниките беа применети анализа на современата литература и скала за проченка на игровни активности. Примерокот се состоеше од 32 деиа со пречки во развојот на возраст од 7-12 години.

Добиените резултати ја потениираа важноста од примена на терапијата преку игра кај дечата со пречки во развојот, со оглед на тоа што кај $72 \%$ од испитаниците, најчеста активност во слободното време е гледање на телевизија или примена на компјутер.

Клучни зборови: ИГРА, ТЕРАПИЈА ПРЕКУ ИГРА, ДЕЦА СО ПРЕЧКИ ВО РАЗВОЈОТ, СЕНЗОМОТОРНА СТИМУЛАЦИЈА.

\section{Вовед}

Првата појава на играта е забележана уште во првите историски записи за човештвото, притоа менувајќи ја својата структура и поставеност во зависност од развојот на општествената култура, поезијата, музиката, танцот, филозофијата и социјалните структури (Drewes, 2006). Значењето на играта за детскиот развој особено го истакнале Обединетите нации (1989) во Конвенцијата за правата на децата, нагласувајќ́ дека играта е развојно најсоодветен и најмоќен медиум за изградба на цврста и здрава врска дете-возрасен, за развој на причинско-последично размислување и контрола на импулсивност, за надминување на стресните ситуации и учење на социјални вештини. Играта не само што придонесува за развојот на детето, дозволувајќи му да учи, да учествува во различни активности и да раз- 
вива нови способности, исто така играта е и индикатор за напредокот и развојот на детето. Како што расте и се развива детето, така се менува и неговата игра.

Децата со посебни потреби претставуваат посебен предизвик кога станува збор играта и игровните активности, посебно истакнувајќк го создавањето на соодветна средина за играње, пред сѐ безбедна, изборот на играчки, адаптирање на посебни уреди и асистивна технологија. Не постојат прецизни истражувања кои ни откриваат детали за играта кај децата со различен вид и степен на пречки во развојот. Анализата на современата литература истакнува дека играта кај децата со пречки во развојот значително се разликува од играта кај нивните врсници, репертоарот е ограничен, а фреквенцијата намалена (Li, 1981; Kaplan \& Kopp, 1988). Гледајќк кај различни видови на попреченост може да се забележи дека кај децата со телесна инвалидност играта е претежно солитарна, статична и краткотрајна (Jennings, Connors, Stegman, Sankaranarayan \& Medolsohn, 1985; Bergen, 1991), кај децата со церебрална парализа и други видови на тешка телесна инвалидност се забележува задоцнета појава на игрите на улога и имагинарните игри (Martin, 2014). Флореј (Florey, 1971) опсервирајќи ги децата со комбинирана попреченост забележала дека нивните игровни активности се пасивни, во седечка положба, со ограничена достапност на материјали и редуцирана на мали моторни активности (Mistrett, Lane, Goets, 2000). Кај интелектуално попречените играта е еднолична, без креативност, преферираат игри без правила, игрите на улоги се оскудни (Ајдински, 2007). Децата со аутизам уживаат во играта, но во склад со нивните карактеристики, играта е премногу лимитирана со нефлексибилна примена на мал и ограничен број на играчки и ја реализираат на репетитивен начин. Засегнатоста на социјалните и комуникативни вештини налага индивидуална игра во најголемиот број на случаи со отпор кон учество на други лица во играта (Lash, McCoy, 2010). При оштетување на видот, децата се соочуваат со проблеми и тешкотии при опсервација и копирање на моделот, па се забележува недостаток на информации и знаења за начинот на играње со соодветни предмети или игри на улоги, сиромашни симболични игри. Исто така ограничената мобилност кај овие деца предизвикува подолготрајна перзистенција на истражувачката фаза (Aslan, 2015).

Покрај лимитираноста како резултат на клиничката слика и способностите на децата со пречки во развојот, социјална депривација настанува и како резултат на ставот и односот на родителите. Нивната улога како партнер во играта е заменета со улога на негувател, медицински опсерватор или координатор, спонтаната интеракција помеѓу родителот и детето е инхибирана од страна на родителската анксиозност за медицинската состојба и влошување на клиничката слика (Mistrett, Lane, Goets, 2000).

Иако играчките имаат потенцијал да создадат силен и позитивен импакт врз социјалниот и когнитивниот развој, понекогаш можат да создадат и фрустрација кај децата, особено во оној момент кога тие не знаат да се справат со нив и наместо да бидат олеснувачи на процесот на учење, можат да го отежнат. Недостатокот на интеракција со играчките и со врсниците, како и напрегањето да се создаде контрола врз физичката и социјалната средина, може да создаде негативно влијание во понатамошниот развој (Bradley, 1985). 


\section{Методологија}

Важноста на играта за целокупниот развој на детето како био-психо-социјално суштество нѐ наведе да спроведеме истражување со кое ќе детерминираме какви видови на игровни активности преферираат децата со различен вид на пречки во развојот, но и колку често се вклучуваат во игровни активности. Беше користен пригоден примерок со 32 испитаника на возраст од 7 до 12 години, од кои 7 со церебрална парализа, 14 со аутизам и 11 со лесна и умерена интелектуална попреченост. Ги користевме методите на компаративна и дескриптивна анализа, како и методот на генерализација, а за собирање на податоците применивме скала за проценка со понуден инвентар на 14 активности. Податоците беа обработени со помош на дескриптивна статистика.

\section{Резултати со дискусија}

Испитаниците беа задолжени да одговорат која од 14 понудени активности најмногу сакаат да ја реализираат во своето слободно време, при тоа за секоја од нив да наведат фреквенција на јавување.

Табела 1. Видови на преферирани активности

\begin{tabular}{|c|c|c|c|c|c|c|c|}
\hline \multirow{2}{*}{ Тип на активност } & \multicolumn{2}{|c|}{$\begin{array}{c}\text { Дали ја правиш } \\
\text { оваа активност }\end{array}$} & \multicolumn{2}{|c|}{$\begin{array}{c}\text { Дали ја сакаш активност } \\
\text { ова丿 }\end{array}$} & \multicolumn{2}{|c|}{$\begin{array}{c}\text { Колку често ја правиш } \\
\text { оваа активност }\end{array}$} \\
\cline { 2 - 8 } & да & не & многу & малку & $\begin{array}{c}\text { многу } \\
\text { често }\end{array}$ & често & ретко \\
\hline Игра со карти & $31.25 \%$ & $68.75 \%$ & $60 \%$ & $40 \%$ & $20 \%$ & $40 \%$ & $40 \%$ \\
\hline Посета на парк & $81.25 \%$ & $18.75 \%$ & $80.77 \%$ & $19.23 \%$ & $42.30 \%$ & $53.84 \%$ & $7.69 \%$ \\
\hline $\begin{array}{c}\text { Разгледување сликов- } \\
\text { ница }\end{array}$ & $59.38 \%$ & $40.62 \%$ & $47.37 \%$ & $52.63 \%$ & $42.10 \%$ & $36.84 \%$ & $15.79 \%$ \\
\hline Играње со топка & $56.25 \%$ & $43.75 \%$ & $66.67 \%$ & $33.33 \%$ & $50 \%$ & $50 \%$ & $/$ \\
\hline Гледање на ТВ & $100 \%$ & $0 \%$ & $81.25 \%$ & $18.75 \%$ & $81.25 \%$ & $18.45 \%$ & $0.03 \%$ \\
\hline Слушање музика & $96.86 \%$ & $3.21 \%$ & $75 \%$ & $25 \%$ & $80.64 \%$ & $6.45 \%$ & $12.90 \%$ \\
\hline $\begin{array}{c}\text { Грижа за домашно ми- } \\
\text { лениче }\end{array}$ & $28.12 \%$ & $71.86 \%$ & $44.44 \%$ & $55.56 \%$ & $11.11 \%$ & $55.55 \%$ & $33.33 \%$ \\
\hline Пеење & $43.75 \%$ & $56.25 \%$ & $64.29 \%$ & $35.71 \%$ & $50 \%$ & $28.57 \%$ & $21.43 \%$ \\
\hline Играње со коцки & $65.62 \%$ & $34.36 \%$ & $61.90 \%$ & $38.09 \%$ & $42.86 \%$ & $38.10 \%$ & $19.05 \%$ \\
\hline Цртање и боење & $56.25 \%$ & $43.75 \%$ & $38.90 \%$ & $61.10 \%$ & $22.22 \%$ & $38.89 \%$ & $44.44 \%$ \\
\hline $\begin{array}{c}\text { Игри на улоги (готве- } \\
\text { ње итн.) }\end{array}$ & $9.36 \%$ & $90.62 \%$ & $/$ & $100 \%$ & $/$ & $/$ & $100 \%$ \\
\hline Играње со пластелин & $56.25 \%$ & $40.63 \%$ & $55.55 \%$ & $44.44 \%$ & $38.89 \%$ & $33.33 \%$ & $33.33 \%$ \\
\hline $\begin{array}{c}\text { Излегување со прија- } \\
\text { тели }\end{array}$ & $46.86 \%$ & $53.13 \%$ & $53.33 \%$ & $46.66 \%$ & $46.67 \%$ & $40 \%$ & $13.13 \%$ \\
\hline $\begin{array}{c}\text { Употреба на компју- } \\
\text { тер }\end{array}$ & $81.25 \%$ & $18.75 \%$ & $84.61 \%$ & $15.38 \%$ & $61.53 \%$ & $30.77 \%$ & $7.70 \%$ \\
\hline
\end{tabular}


Од понудените активности во табела 1 може да се забележи дека најголемиот број од испитаниците $81.25 \%$ како најчеста активност ја наведуваат гледање на телевизија, $80.64 \%$ наведуваат слушање на музика, а $61.53 \%$ употреба на компјутер, што директно го потврдува ставот добиен во досегашните истражувања, дека децата со пречки во развојот имаат намалени игровни активности. Во однос на понудените игри најголемиот број на добиени одговори се однесуваат на игри со топка, кај $50 \%$ од испитаниците, кај $42.86 \%$ често се применуваат коцките во конструктивните игри, $42.10 \%$ во слободното време разгледуваат сликовнци, а $38.89 \%$ преферираат игри со пластелин и моделирање. Најмал број од испитаниците ја посочиле играта на улоги.

Ако се разгледуваат одговорите во однос на вид на попреченост може да се забележи присуство на статистички значајна разлика за одделни видови на активности во однос на фреквенцијата на јавување со примена на хи квадрат тестот за табели на контингенција. Играта со карти најмногу ја играат испитаниците со интелектуална попреченост (Таб. 2), што се должи на карактеристиките на испитаниците, односно мобилната ограниченост и солитарните игри кај лицата со телесна инвалидност и нарушени комуникативни и интеракциски способности кај лицата со аутизам. Игрите со топка се сретнуваат кај сите категории, со тоа што испитаниците со интелектуална попреченост најчесто ја применуваат, а лицата со аутизам ја играат, но ретко (Таб. 3). Игрите со коцки поголемиот дел од испитаниците со церебрална парализа и аутизам не ги сакаат, но тие што ги играат играат често. Од испитаниците со интелектуална попреченост сите ја играат, но речиси е еднаков бројот на оние кои сакаат да ја играат и оние кои немаат желба за истата (Таб. 4).

Табела 2. Фреквенција на игри со карти

\begin{tabular}{|c|c|c|c|c|c|c|c|c|}
\hline \multirow{2}{*}{ Активност } & Дијагноза & \multicolumn{2}{|c|}{$\begin{array}{c}\text { Дали ја пра- } \\
\text { виш оваа ак- } \\
\text { тивност? }\end{array}$} & $\begin{array}{c}\text { Дали ја сакаш } \\
\text { оваа актив- } \\
\text { ност? }\end{array}$ & \multicolumn{2}{|c|}{$\begin{array}{c}\text { Колку често ја правиш } \\
\text { оваа активност? }\end{array}$} \\
\hline \multirow{3}{*}{$\begin{array}{c}1 . \text { Игра со } \\
\text { карти }\end{array}$} & $\begin{array}{c}\text { Церебрална } \\
\text { парализа }\end{array}$ & Да & Не & Многу & Малку & $\begin{array}{c}\text { Многу } \\
\text { често }\end{array}$ & Често & Ретко \\
\cline { 2 - 9 } & 1 & 6 & 1 & 0 & 1 & 0 & 0 \\
\cline { 2 - 9 } & Аутизам & 2 & 12 & 1 & 1 & 0 & 0 & 2 \\
\cline { 2 - 9 } & \multicolumn{1}{|l|}{ ЛИП } & 7 & 4 & 5 & 2 & 2 & 2 & 3 \\
\hline
\end{tabular}

$\chi^{2}=8.1832 ; p=0.016712 ; p<0.05$. 
Табела 3. Фреквенција на игри со топка

\begin{tabular}{|c|c|c|c|c|c|c|c|c|c|}
\hline $\begin{array}{c}\text { Актив- } \\
\text { ност }\end{array}$ & $\begin{array}{c}\text { Дијаг- } \\
\text { ноза }\end{array}$ & Дали . & $\begin{array}{l}\text { оавиш } \\
\text { зност? }\end{array}$ & $\begin{array}{r}\text { Дали } \\
\text { a }\end{array}$ & $\begin{array}{l}\text { а сака } \\
\text { гивно }\end{array}$ & $\begin{array}{l}\text { оваа } \\
?\end{array}$ & $\begin{array}{l}\text { Колк } \\
\text { виш о }\end{array}$ & $\begin{array}{l}\text { несто } \\
\text { а ак? }\end{array}$ & $\begin{array}{l}\text { пра- } \\
\text { ност? }\end{array}$ \\
\hline \multirow{4}{*}{$\begin{array}{l}\text { 4. Игра со } \\
\text { топка }\end{array}$} & \multirow{2}{*}{$\begin{array}{c}\text { Цереб- } \\
\text { рална } \\
\text { парализа }\end{array}$} & Да & $\mathrm{He}$ & $\begin{array}{c}\text { Мно } \\
\text { гу }\end{array}$ & $\begin{array}{c}\text { Мал } \\
\text { ку }\end{array}$ & $\begin{array}{c}\text { Нe ja } \\
\text { са } \\
\text { кам }\end{array}$ & $\begin{array}{c}\text { Мно } \\
\text { гу чес } \\
\text { то }\end{array}$ & $\begin{array}{l}\text { Чеc } \\
\text { то }\end{array}$ & $\begin{array}{l}\text { Рет } \\
\text { ко }\end{array}$ \\
\hline & & 4 & 3 & 3 & 1 & 0 & 2 & 2 & 0 \\
\hline & Аутизам & 4 & 10 & 2 & 2 & 0 & 1 & 0 & 3 \\
\hline & ЛИП & 11 & 0 & 10 & 1 & 0 & 8 & 3 & 0 \\
\hline
\end{tabular}

$\chi^{2}=13.048 ; p=0.001468 ; p<0.05$.

Табела 4. Фреквенција на игри со коцки

\begin{tabular}{|c|c|c|c|c|c|c|c|c|c|}
\hline $\begin{array}{l}\text { Актив- } \\
\text { ност }\end{array}$ & $\begin{array}{c}\text { Дијаг- } \\
\text { ноза }\end{array}$ & $\begin{array}{l}\text { Дали } \\
\text { оваа а }\end{array}$ & $\begin{array}{l}\text { оавиш } \\
\text { зност? }\end{array}$ & $\begin{array}{r}\text { Дали } \\
\mathrm{a}\end{array}$ & сакс & $\begin{array}{l}\text { оваа } \\
?\end{array}$ & $\begin{array}{l}\text { Колк } \\
\text { виш о }\end{array}$ & $\begin{array}{l}\text { несто } \\
\text { а акт }\end{array}$ & $\begin{array}{l}\text { пра- } \\
\text { ност? }\end{array}$ \\
\hline \multirow{4}{*}{$\begin{array}{l}\text { 9. Игра со } \\
\text { коцки }\end{array}$} & \multirow{2}{*}{$\begin{array}{c}\text { Цереб- } \\
\text { рална } \\
\text { парализа }\end{array}$} & Да & $\mathrm{He}$ & $\begin{array}{c}\text { Мно } \\
\text { гу }\end{array}$ & $\begin{array}{c}\text { Мал } \\
\text { ку }\end{array}$ & $\begin{array}{c}\text { He ja } \\
\text { са } \\
\text { кам }\end{array}$ & $\begin{array}{c}\text { Мно } \\
\text { гу чес } \\
\text { то }\end{array}$ & $\begin{array}{l}\text { Чec } \\
\text { ro }\end{array}$ & $\begin{array}{l}\text { Рет } \\
\text { ко }\end{array}$ \\
\hline & & 4 & 3 & 2 & 2 & 0 & 1 & 3 & 0 \\
\hline & Аутизам & 5 & 9 & 4 & 1 & 0 & 1 & 4 & 0 \\
\hline & ЛИП & 11 & 0 & 6 & 3 & 2 & 4 & 4 & 3 \\
\hline
\end{tabular}

$\chi^{2}=10.9714 ; \mathrm{p}=0.004146 ; \mathrm{p}<0.05$.

Бесио и Карнечеци (Besio \& Carnechecci, 2014) во својата студија истакнале дека кај децата со пречки во развојот, во зависност од типот на функционално ограничување, спонтаноста и активноста на играта стануваат проблематични. Тие забележале дека децата со когнитивни и интелектуални пречки тешко остваруваат соработка со врсниците во текот на играта, па затоа почесто играат сами, сакаат да повторуваат исти активности, им недостасува симболичка игра.

Хистинис и Керол (Hestenes \& Carroll, 2000) правеле компарација помеѓу изборот на активности и типот на игра, при што забележале дека не постои разлика помеѓу врсниците со и без пречки во развојот во однос на изборот на игровната активност, но постои разлика во обликот на игра, децата со пречки во развојот повеќе одбираат самостојна игра без кооперација и интеракција со другите.

Иако примерокот е мал и пригоден, а врз основа на тоа резултатите не можат да се генерализираат, сепак одат во прилог на досегашните истражувања, при тоа истакнувајќ́ ја потребата за организација на терапија со игра кај децата со пречки во развојот во насока на овозможување на стимулативна средина за опти- 
мален развој на преостанатите способности. Постојат повеќе видови на терапија со игра, класифицирани во три основни категории (Рашиќ-Цаневска, 2016):

- директивна или структурирана терапија со игра - терапевтот има активна и водечка улога во играта на детето, посочувајќи структура, насока и начин на интерпретација на играта. Некои од популарните форми на директивна или насочена терапија со игра се: когнитивно-бихејвиоралната терапија со игра, ослободувачката игра и слично;

- недирективна терапија со игра, со централно поставување на детето терапевтот има поддржувачка, а не насочувачка улога, детето има можност самото да се насочува и води, да одбира игра која ја преферира од понудените, да одбира играчки и материјали за работа;

- семејна терапија со игра - главната одлика на оваа категорија на терапија со игра е поддршка и стимулација на врската родител-дете, со што на родителите им се помага да развијат способности за подобро поврзување со детето, воочување и решавање на бихејвиоралните проблеми кај своето дете. Семејната терапија со игра може да биде насочена кон возрасните или кон децата.

Терапијата со игра се применува како изборен вид на интервенција во третманот на деца, но и возрасни во институции за ментално здравје, училишта и предучилишни установи, дневни центри, болници и сл. Истражувањата посочуваат дека терапијата со игра им помага на децата да станат поодговорни за своето однесување и да развијат поуспешни стратегии; да развијат нови, креативни решенија на проблемските ситуации; да ја зголемат самодовербата и прифаќањето на себе, но и на другите; да научат да доживуваат емоции и истите да ги изразуваат; да научат за емпатија и почит; да развијат нови сензомоторни способност; да ги подобрат когнитивните способности (Reddy, Files-Hall, \& Schaefer, 2005). Томас (Thomas, 2011) го истражувал ефектот од примена на терапија со игра кај 3072 испитаника со емоционални, бихејвиорални и проблеми во менталното здравје, при што $74 \%$ од испитаниците со полесни проблеми манифестирале подобрување, додека пак дури $83 \%$ од испитаниците со потежок облик на проблеми покажале позитивни ефекти од примената на терапија со игра.

Развојните ограничувања во експресивните и рецептивните јазични способности, ограничениот вокабулар и ограниченото апстрактно размислување предизвикува отежната ефикасна комуникација на децата. Една од најголемата моќ на играта, опишана во литературата е нејзината комуникациска моќ. Во играта децата се способни подобро да ги изразат своите свесни размислувања и чувства, отколку изразувањето преку зборови, се чувствуваат слободни во примената на конкретни игровни активности и материјали. Употребата на симболична репрезентација и експресија преку различни кукли овозможува емоционална дистанцираност од емотивните искуства, мисли и чувства. Преку индиректна експресија во играта детето може да развие свесност за проблематичните влијанија и сеќавања и да започне процес на лекување (заздравување) (Schaefer, 1999). Со специјално избрани играчки, игри и материјали, преку терапевтска и природна стимулација, детето може да ги открие своите потсвесни конфликти, со посредство на одбранбените 
механизми на личноста како што се: проекција, замена и симболизација (Klein, 1955). Играта може да помогне децата повторно да ги преживуваат стресните и трауматични искуства, притоа развивајќи чувства на моќност и контрола над нив. Преку репетитивни стресни активности се зголемува менталната толеранција кај децата и се овозможува надминување на лошите мисли и чувства. Децата покажуваат природна тенденција за соочување со екстерни настани и трауми со посредство на играта (пример: по гледање на хорор сцени, многу деца во играта градат кули од коцки и рушат авиони во нив). Пост-трауматската игра најефикасно се применува за предизвикување на интерни промени во личноста на трауматизираното дете (Terr, 1990, p. 299). Анксиозноста на децата како резултат на стресни животни ситуации, како што се преселба на семејството, започнување со училиште, раѓање на брат или сестра или, пак, посета на доктор, може да биде намалена преку симболична игра на слични настани претходно, како подготовка на детето (Wohl \& Hightower, 2001).

Од особено значење за децата со посебни потреби е создавањето на цврста и здрава врска со родителите. Играта е основен медиум за воспоставување на позитивна емоционална врска помеѓу детето и родителите. „Чекор по чекор“ сесиите инструирани од страна на терапевтот се користат за креирање на позитивна искуства помеѓу детето и родителите непосредно преку заедничка вклученост во различни видови игри. По сесиите се забележуваат подобра емпатија кај родителите, позитивни промени во семејната средина, подобра перцепција на проблемите со кои се соочува детето, можноста за негово приспособување и сликата за себе кај детето и слично (Van Fleet \& Guerney, 2003).

\section{Заклучок}

Од суштинско значење е откривањето на методи кои би овозможиле зголемено учество во игровните активности на децата со пречки во развојот. Креирањето на безбедна и стимулативна средина, каде детето ќе може непречено да игра, запознавајќи се себе и светот е предизвик за родителите, наставниците, терапевтите и сите профили вклучени во третманот и рехабилитацијата на децата со посебни потреби. Сите деца мора да имаат време за игра, време во кое ќе се чувствуваат слободни и надвор од границите на светот кој ги опкружува и кој понекогаш знае да предизвика стрес. Токму преку ваквите искуства и интеракции, децата стануваат самоуверени, независни, способни да ја користат својата имагинација, да ги контролираат своите тела и да ги развијат нивните интелектуални, социјални и емоционални способности. 


\section{Литература:}

Ајдински, Г. (2007). Олигофренологија. Скопје: Филозофски факултет

Aslan, C., Ozdemir, S., Demirurek, P., Cotuk, H. (2015). Examining play diversity and play complexity of typically developing children and children with visual impairments. In International journal of early intervention 2 (7); p:212-237.

Bergen, D. (1991, April). Play as the vehicle for early intervention with at-risk infants and toddlers. Paper presented at the annual meeting of the American Educational Research Association, Chicago, IL.

Besio, S., Carnecheci, M. (2014). The challenge of a research network on play for children with disabilities. Procedia - Social and Behavioral Sciences 146 ( 2014 ) 9 -14 .

Bradley, R., H. (1985). Social-cognitive development and toys. Topics in Early Childhood Special Education, 5(3), 11-30.

Drewes, A., A. (2006). Play-based interventions. Journal of Early Childhood and Infant Psychology, 2, 139-156.

Florey, L. (1971). An approach to play and play development. The American Journal of Occupational Therapy, 15(6), 275-280.

Hestenes, L., Carroll, L. (2000). The play interactions of young children with and without disabilities: Individual and environmental influences. In Early Childhood Research Quarterly 2(15); 229-246.

Jennings, K.D., Connors, R.E., Stegman, C.E., Sankaranarayan, P., and Mendelsohn, S. (1985). Mastery motivation in young preschoolers: Effect of a physical handicap and implications for educational programming. Journal of the Division for Early Childhood, 19(2), 162-169.

Kaplan-Snoff, M., Brewster, A., Stillwell, J., \& Bergen, D. ( 1988). In D. Bergen (Ed.), Play: As a mediumfor learning and development: A handbook of theory and practice (pp. 137-161). Portsmouth, NH: Heinemann.

Klein, M. (1955). The psychoanalytic play technique. American Journal of Orthopsychiatry, 35, 223-237.

Lash, E., McCoy, P. (2010). Play and autism. Huntington: Autism Training Center at Marshall University.

Li A.K.F. (1981). Play and the mentally retarded child. Mental Retardation, 19, 121126.

Martin, S. (2014). Play in Children with Motor Disabilities. University of Kentucky.

Mistrett, S., Lane, S., Goets, A. (2000). Assisting Families in Creating Play Environments for Children with Disabilities. U.S. Department of Education.

Рашиќ-Цаневска, О. (2016). Окупациона терапија. Скопје: Филозофски факултет.

Reddy, L., Files-Hall, T., \& Schaefer, C. (2005). Empirically Based Play Interventions for Children. San Francisco: Jossey-Bass. 
Schaefer, C. E. (1999). Curative factors in play therapy. Journal for the Professional Counselor, 14, 1, 7-16.

Terr, L. (1990). Too scared to cry: Psychic trauma in childhood. New York: HarperCollins.

Thomas, J. (2011). An Effective Way of Alleviating Children's Emotional, Behaviour and Mental Health Problems - the Latest Research. The Coach House, Belmont Road.

United Nations Convention on the Rights of the Child (1989). Article 31.1. Retreived April 20, 2008, from http://ww2.ohchr.org/English/law/crc .htm.

VanFleet, R., \& Guerney, L. (Eds.). (2003). Casebook of Filial Therapy. Boiling Springs, PA: Play Therapy Press.

Wohl, N., \& Hightower, D. (2001). Primary Mental Health Project: A Schoolbased prevention program. In A. A. Drewes, L. J. Carey, \& C. E. Schaefer (Eds.),School-basedplaytherapy(pp.277-296).NewYork:JohnWiley\&Sons. 
Olivera RASHIKJ CANEVSKA

\section{PLAY AS ACTIVITY AND PLAY AS THERAPY \\ IN CHILDREN WITH DISABILITIES}

\section{Summary}

The play presents a normal expression in children, which can be affected by the ethnicity, language, religion or other cultural aspects. Not only the central place it has, but also it is crucial for the child's development, intensive motor and sensory stimulation, which are results of the play, help the normal development of the brain and prevent neuronal loss. On the other hand, is not only important to promote normal childhood development, it has invaluable therapeutic benefits.

The main goal of the study was to determinate the frequency and the type of play activities that children with disabilities prefer, as well as to potentiate the therapeutic power of the play. There were used methods of comparative and descriptive analysis and the method of generalization. A literature review and assessment scales for play activities were used as techniques. The sample was consisted of 32 examinees with disabilities aged between 7 and 12 years.

The obtained results highlighted the importance of the application of play therapy for children with disabilities, according to the fact that $82 \%$ of examinees most of the leisure time spend in watching TV or using a computer.

Key words: PLAY, PLAY THERAPY, CHILDREN WITH DISABILITIES, SENSOMOTOR STIMULATION. 